\title{
(A)MORAL MACHIAVELLIANISM - ANALYSIS OF THE NICCOLO MACHIAVELLI CONCEPT
}

\begin{abstract}
Otto von Bismarck once commented that people ought not to watch the making of sausages or politics, as both activities may result in disgust and lots of doubts for sensitive observers. The average observer has, on daily basis, excellent opportunities to watch all sorts of on-going struggles in the political arena. Participants at such events make use of various methods to convince their viewers that they are, indeed, people that uphold the rule of law and values that constitute them. Their performance has, at the same time, a second covert undertone whose content is the fight, devoid of any scruples, for interest groups they represent. However, the real face remain concealed, while we only see that which they want to show us. Contemporary politics gives the impression of a continuous power struggle and its execution, while the techniques and mechanisms being applied are far from ideal. Politics exercises its own game rules at a level often characterized by activities often referred to by citizens as pejorative and are morally disapproved although this ethical ennoblement of vice is common in politics. That, which is literally regarded in typical human relations as breaking the rules is depicted as a virtue and glorifiable at the level of politics. It has long been observed that while minor rogues end up in prison, monuments ${ }^{2}$ are often erected for grand criminals. The main precursor of efficiency of politics as a core value was Niccolo Machiavelli. The article is an attempt to analyse his views on politics, identify core concepts that are often applied in his discussions as well as possibilities of application of his concepts in contemporary solutions both in politics and beyond.
\end{abstract}

Keywords: ethics, morality, politics, Machiavellianism, Niccolo Machiavelli.

\section{INTRODUCTION}

The juxtaposition of such seemingly diametrically different phenomena of social life like ethics and politics may be seen as shocking to many. Politics is, in popular public opinion, associated with something rather contrary to ethics. It is often believed to be solely a cold-blooded game to gain and execute authority, where the only thing that matters is effectiveness. Any moral evaluation of political activities bothers on absurdity. The winners are always right as the end justifies the means. Such conclusions can be drawn both from centuries-old historical experience and the analysis of techniques of governance. However, the answers from the ethical perspective are rarely zero-one or clear-cut. Presuming that moral order also applies to life of countries, it does not, however, exhaustively deal with the issue of „,politics and morality”. Politicians are in unison that nation states do not exemplify the same morality as individual persons and that State morality is a morality of self-affirmation and not self-destruction. The sovereign task of the State is to maintain and defend its autonomy and might, even at the cost of actions

\footnotetext{
${ }^{1}$ Dr Justyna Stecko, Department of Humanities, Faculty of Management, Rzeszów University of Technology, ul. Poznańska 1, 35-084 Rzeszów, tel. 017 8651204, e-mail: jstecko@prz.edu.pl

${ }^{2}$ Z. Stawrowski, O niemoralności i moralności polityki: http://www.opoka.org.pl/biblioteka///IK/polityka_moraln2.html
} 
that do not correlate with morality. This often translates to the saying that an end justifies any means.

\section{NICCOLO MACHIAVELLI - AMO LA PATRIA MIA PIU DELL'ANIMA}

A key figure in discussions on such solutions in the political sphere is Niccolo Machiavelli. Of course his texts are worthy of study not necessarily for the sole need of comparison of moral principles and engaging in efficient politics, but rather to never forget there are people, especially in the sphere of political life, who without qualms break such rules. Frederick II, the author of „Anti-Machiavelli” postulates that ,the world is like a round of game in which both honest players and scammers participate. The Prince that wishes to participate in the round, attempting to avoid falling prey of the fraud, must understand how to cheat, not necessarily for him to apply such knowledge, but to avoid being cheated"3.

Machiavelli, in contrast to ancient philosophers and Christian theologians idealized love for his homeland above all others. As he said, he love his country more than his own soul (amo la patria mia piu dell'anima). He was of the opinion that the nation's welfare is of paramount value and one must not consider it as being justified or not, glorious or shameful. One must do whatever is possible to preserve his country's freedom and independence irrespective of the circumstances. His courage and controversial thoughts perfectly reflects Machiavelli's dream: „Machiavelli was said to have seen in dream a crowd of beggars clothed in rags that seemed unhappy, who in response to his question concerning their identity said: We are saints and blessed and heading for heaven. He later saw a crowd of people of noble and dignified appearance, dressed in ceremonial robes, that seriously deliberated on key political issues. He identified, amongst them, great philosophers and ancient historians, authors of fundamental works on politics and the nation - Plato, Plutarch and Tacitus. He also asked them who they were and their destination. Their response was: We are damned and going to hell. In concluding his story, Machiavelli observed that he would have been better off in hell debating politics with great personalities of the ancient world than in heaven, where he would have died in boredom in the company of saints and the blessed"4.

The most controversial and yet the most discussed work of Machiavelli is not his collection of myths about past eras, but first and foremost his historical work on effective governance. Historical knowledge was for him of extreme value as he was certain that "whatever happens in this world has its parallel in recent past. All things are achieved by people, who were guided and continue to be guided by the same passions, and their actions should therefore yield the same results" ${ }^{\text {. }}$. Hence, , in order to predict the future, it is necessary to know the past" . The study of history therefore seems to be the best way to know man, including the principles of efficiency of activities.

\footnotetext{
${ }^{3}$ Cyt za A. Riklin, Die Führungslehre von Niccolò Machiavelli, Bern 1996, s. 29.

${ }^{4}$ M. Viroli, Uśmiech Machiavellego. Biografia, PWN 2006, s.11.

${ }^{5}$ N. Machiavelli, Książę, [w:] N. Machiavelli, Książę; Rozważania, tłum. W. Rzymowski, K.

Żaboklicki, Warszawa 1993, s. 13.

${ }^{6}$ Ibidem, s. 15
} 


\section{MORALITY OR DOUBLE MORALITY?}

What was crucial for Machiavelli were questions concerning separation of politics from morality or rather the analysis of types of morality, resulting in collision with only one of them. One can, of course, analyze theoretical passages from the Prince, pointing out the basic, often shocking advice such as that authority can apply cruel punishments on people who do not conform directly with designated social rules. In Machiavelli's opinion leniency and mercy in respect of subjects can result in chaos and riots to the detriment of the generality, while severe executions which foil development of such acts affects only selected few. Cruelty is only to be applied to strengthen authority. Machiavelli advises that „, repression ought to be exerted in lump sum, thus making it less painful as each is less felt.. Wealth, on the other hand, ought to be dispensed gradually, so that subjects can savour it better"7. In some other place he says: ,as every winner gets to grips with governance it ought to prepare and summarily commit all necessary cruelty, as by avoiding returning to and repeating them daily comfort could be granted to the populace and win their hearts through benevolence" 8

In Machiavelli's words, ,since the sympathy of the people depend on their willingness, but terror lies in the hands of the Prince, his intelligence will therefore be based on what belongs to him, but not on what belongs to others"9. The authority ought to enforce its rule relying on fear and not the sympathy of its subjects, whom it finds more difficult to govern. Inciting fear should not be confused with incitement for hatred. Since the latter is dangerous for authorities, to avoid this the authority would have to avoid violating his subjects' rights. The ruler, does not, however, have to keep to his word, if fulfilling them might harm him. In quoting the author of the Prince , ,since [...] evil willingness of the populace excel and oaths sworn to fail, so you, too, need not observe them. Moreover, the Prince never lacks handy legitimate reasons for the coloration of perfidy" 10

Machiavelli equally advises that ,if conquered countries are accustomed to selfgovernance and freedom there exist three ways to retain them: first, destroy them, second establish your seat of government there and third allow them to retain their laws but extract fixed incomes from them, and third create an internal oligarchic government, that would ensure their friendship towards you. Such a government created by the Prince realizes that it cannot get along without his friendship and power, and as such it needs to strive to sustain it" 11

Although the aforementioned principles do not seem moral, some aspects which drew the attention of Isaiah Berlin are worthy of mention. Berlin postulates that such principles have nothing to do with principles of morality, rather they mainly Christian morality. They in Berlin's opinion „reject in essence one type of morality namely, Christian morality. However, it is not rejected in favour of something else that cannot be referred to as morality, but only a game of certain skills, an activity referred to as political, something that is neutral in respect of man's ultimate goal. Thus, it is not rejected in favour of

\footnotetext{
${ }^{7}$ Ibidem, s. 70.

${ }^{8}$ Ibidem, s. 61

${ }^{9}$ Ibidem, s. 99.

${ }^{10}$ Ibidem, s. 101.

${ }^{11}$ Ibidem, s. 48.
} 
something that is not ethical"12. The negation of Christian morality is the outcome of critical views on Christian values from the perspective of an ideally functioning State. It does not, however, attempt to prove that the Christian religion is not genuine. It does not apply the true-false categories, and neither is Machiavelli interested in if Christianity is right or wrong. The only thing that is of interest to the thinker are the specific sociopolitical impacts, which are the results of the value beliefs of the citizens. Hence Machiavelli dismisses Christian morality in favour of a different morality, which Berlin refers as paganism or classical.

It is, in Berlin's opinion, ,an ethical system [...], that existed in the ancient Greek polis, which was clearly expounded by Aristotle. Since humanity is created as beings living in communities, their social roles constitute the highest values from which not only all others derive, but using them one can identify the individual goals of entities"13. The values of the Christian world diametrically differs from the values and principles of a pagan world. The former despises this mundane world and its virtues that are tenable on earth, while the latter approvingly treasures the virtues of daily life.

The Chief values propagated by Christian thinking are humility, mercy, forgiveness, gentleness, while the main goals of life are the eschatological assumptions. However, the Christian disregard for temporality, according to Machiavelli resulted in ,weakness being rooted in the world, bequeathing the world a prey to the wicked, who un-disturbingly controls it, knowing that man in his desire to attain paradise are more inclined to bear the wrong than to avenge them "14. The analysis as well as the criticism of the principles proclaimed by Christianity is the subject of the author of the Prince through the juxtaposition of the Christian religion and morality with the pagan religion and morality. The differences between them, for Machiavelli, seem to be the main reason why the pagan Rome was a power, but the Christian Italy weak and tattered. These are two varying approaches to values, principles and in tune with them morality, including their associated ideals. With this approach by Machiavelli, it becomes rather clear that the author was not interested in separating politics from morality, but in seeking the integral parts of politics and morality that is understood differently. The author does not separate ethics from morality, rather he enunciates two types of morality.

Machiavelli sees, in religion, a large room for manipulation and possibilities of its utilitarian application. He, on several occasions, advised rulers to offer support for religion, even if it appears to them false for religion has sometimes been applied in history to successfully quell riots and institute new laws. This knowledge is of immense significance as humans, in Machiavelli's opinion, are inherently evil and egoistic. „It can be generally said of people [...], that they tend to be ungrateful, fickle, hypocritical, cowardly in case of danger, profit-minded and as long as you provide for their well-being, they will remain dedicated, willing to sacrifice blood, property, their own and children's lives [...] for you if the danger is far off, but as soon as it draws near, they will turn against you" ${ }^{15}$. It is, however, possible to transform humans as they are naturally amenable, „man is an entity extremely susceptible to shaping to a greater extents hitherto unknown. If man

\footnotetext{
${ }^{12}$ I. Berlin, Oryginalność Machiavellego, tłum. Z. Dorosz, „Literatura na Świecie”, 1986/6, s. 237.

${ }^{13}$ Ibidem, s. 236.

${ }^{14}$ N. Machiavelli, op.cit., s. 394.

${ }^{15}$ Ibidem, s. 98.
} 
is not naturally oriented towards virtue or excellence and has no natural human goals, he can set for himself any goal he desires since man is almost infinitely amenable"16.

Interestingly, while on the one hand there appears a sort of critique of the Christian thinking, Machiavelli, on the other hand, sees advantages in it. Christianity could through its humanitarian activities modify human nature by weakening his egoism and the widely understood evil as the amenable nature of man enables positive changes as well. Although, in Berlin's mind, humans can be socialized and its nature modified, it will, however, never be an ideal or holy entity ${ }^{17}$. Machiavelli, in selecting values of the pagan world uses coincidentally the semantics of Christian thinking. He often defines the terms "good" and „evil" with a Christian understanding. He affirms, among other things, that for the Prince to hold on to power, „he must learn not to be virtuous" 18 or that hatred can provoke „both proper and improper behaviours" 19 . The highest virtue is, for the author of the Prince the welfare of the fatherland. The entire society ought to be ready for the greatest sacrifice for a common good namely, the autonomy of the State and its proper existence. One should forego the individual's morality and not to hesitate in case of threats to the good of the country. „When it is a matter of saving the fatherland, one should not be guided by what is right or wrong, merciful or cruel nor glorious or shameful. Above everything else, one consideration at such times should be to ensure its survival and protect its freedom" 20 .

Machiavelli seems not to have as much separated ethics from politics, but rather distinguished two value systems and in consequence two types of morality, the Christian and pagan. What seems more practical from the perspective of the ruling class are utilitarian values to which contemporary ethicists often refer.

What is, therefore, Machiavellianism? It is a set of political and social activities that relies on severity and shrewdness, the efficiency of activities that dwell on the slogan ,the end justifies the means". Machiavellianism, as a political doctrine holds that virtue and efficient politics must be geared, primarily, to achieve set objectives.

Machiavelli divides political activity into only two categories namely, those that result in success or failure. History never judges bad winners as efficiency matters ${ }^{21}$ while political success may justify anything. Machiavelli unrelentingly offered advice in private matters that may also be regarded as political tips, for example: ,it is better to achieve something and regret than not to achieve anything and regret ${ }^{22}$ ". Machiavelli's courage lies in the fact that he loudly said that, which others have for long confessed to in their minds. He believed that political correctness depended not only on upholding standards, but also on the possibility of their violations by the ruling class. Do moral restrictions depend on prevailing political circumstances? If a ruler can cheat based on his political ideals, does that mean he can kill as well? Machiavelli agrees with this and does not only

\footnotetext{
${ }^{16}$ L. Strauss, Czym jest filozofia polityki?, [w:] L. Strauss, Sokratejskie pytania, tłum. P. Maciejko, Warszawa 1998., s. 93.

${ }^{17}$ I. Berlin, Oryginalność Machiavellego, op. cit., s. 233.

${ }^{18}$ N. Machiavelli, op. cit., s. 92.

${ }^{19}$ Ibidem, s. 107.

${ }^{20}$ Ibidem, s. 612

${ }^{21} \mathrm{http} / / / \mathrm{www} \cdot$ racjonalista.pl/kk.php/t,2155

${ }^{22}$ M. Viroli, Uśmiech Machiavellego. Biografia, PWN 2006, s. 173.
} 
defends lies but also political assassinations ${ }^{23}$. It is difficult to distinguish virtue from evil as they are both intermingling elements, while the world represents their binding component. Virtuous and evil behaviours take root in the same substrate, which is made up of motives of human conduct. These elements can swiftly permeate between one and the other.

\section{CONCLUSIONS}

Machiavellianism that had been for several years criticized, returned to favour in the second half of the 20th century. Anthony Jay's book, „Management and Machiavelli" ${ }^{24} \mathrm{drew}$ lots of attention in the sixties. Its purpose, according to the sub-title, was to analyse ,the art of retaining top position in our organized world”. Jay accused contemporary teachings on company management of having low levels of systemic analysis, amongst others. In his opinion, an appropriate analysis of management in economic entities ${ }^{25}$ is only possible in respect of experiences in political history.

A creative approach at the level of psychology was in turn suggested by Richard Christie and Florence Geis of the University of Columbia. They designed a questionnaire and a game based on Machiavelli's Prince ${ }^{26}$, that aimed to test the tendency to manipulate people. „The Machiavellianism Scale" contains fragments drawn from Machiavelli as well as fictitious statements suggested by psychologists. While analysing the questionnaire results Christie and Geis observed that Machiavelli followers had more utilitarian than moral approach in their interactions with others. Consequently, they cope better than the average person in negotiations and bargaining as they can effectively resist social stress. They are likewise better at lying and are more successful in highly emotional situations due to their ability to keep their heads cool, among other things. As can be observed, corporate efficiency also draws from non-ethical activities. Although entrepreneurs and politicians would not admit to their fascination or inspiration of Machiavellian principles, they are, however, overtly noticeable in their activities, both at the national and international levels.

\section{BIBLIOGRAPHY}

[1] Berlin I., Oryginalność Machiavellego, tłum. Z. Dorosz, „Literatura na Świecie”, 1986/6.

[2] Christie R., Geis F., Studies in Machiavellianism, Academic Press, Nowy Jork 1970.

[3] Jay A., Management and Machiavelli, Toronto 1967.

[4] Machiavelli N., Książe, [w:] tenże, Książe; Rozważania, tłum. W. Rzymowski, K. Żaboklicki, Warszawa 1993.

[5] Maneli M., Historia doktryn polityczno-prawnych, Warszawa 1968, t. II.

[6] Riklin A., Die Führungslehre von Niccolò Machiavelli, Bern 1996,

\footnotetext{
${ }^{23} \mathrm{http}: / /$ www.racjonalista.pl/kk.php/t,2155; por . także M. Maneli, Historia doktryn politycznoprawnych, Warszawa 1968, t. II , s.11-22.

${ }^{24}$ A. Jay, Management and Machiavelli, Toronto 1967.

${ }^{25}$ A. Riklin, Die Führungslehre von Niccolò Machiavelli, Bern 1996,

${ }^{26}$ R. Christie, F. Geis, Studies in Machiavellianism, Academic Press, Nowy Jork 1970.
} 
[7] Stawrowski Z., O niemoralności i moralności polityki: http://www.opoka.org.pl/biblioteka/I/IK/polityka_moraln2.html

[8] Strauss L., Czym jest filozofia polityki?, [w:] L. Strauss, Sokratejskie pytania, tłum. P. Maciejko, Warszawa 1998.

[9] Viroli M., Uśmiech Machiavellego. Biografia, PWN 2006.

[10]http://www.racjonalista.pl/kk.php/t,2155

\section{(A)MORALNY MACHIAWELIZM - ANALIZA KONCEPCJI NICCOLO}

\section{MACHIAVELLEGO}

Otto von Bismarck wyraził kiedyś opinię, że ludzie nie powinni oglądać tego, jak się robi parówki i politykę, ponieważ obie te czynności mogą wywołać wśród wrażliwych obserwatorów niesmak i liczne wątpliwości. Przeciętny obserwator każdego dnia ma doskonała okazję przyglądania się wszelkiego rodzaju zmaganiom mającym miejsce na scenie politycznej. Aktorzy tego spektaklu wykorzystują różnorakie metody, aby przekonać widzów, że w swej istocie są ludźmi przestrzegającymi zasad i wartości, które ich konstytuują. Jednocześnie spektakl ma drugą zawoalowaną odsłonę, której treścią jest pozbawiona skrupułów walka o interesy grupy społecznej, którą się reprezentuje. Jednak prawdziwa twarz zwykle zostaje w ukryciu a my widzimy jedynie to, co zechciano nam pokazać. Polityka współczesna sprawia wrażenie ciągłej walki o władzę i jej sprawowanie, zaś wykorzystywane techniki i mechanizmy bywają dalekie od ideałów. Polityka rządzi się własnymi regułami a płaszczyznę tę często cechują działania, które przez obywateli określane są jako pejoratywne i podlegają moralnej dezaprobacie, jednak w polityce dochodzi czesto to etycznej nobilitacji występku. To, co na poziomie zwykłych stosunków międzyludzkich uchodzi powszechnie za łamanie zasad, na poziomie polityki przedstawiane jest często jako cnota i powód do chwały. Już dawno zauważono, że drobnych rzezimieszków zamyka się do więzień, wielkim zbrodniarzom buduje się pomniki ${ }^{27}$. Prekursorem skuteczności w polityce jako nadrzędnej wartości był przede wszystkim Nikolo Machiavelli. Artykuł jest próbą analizy spojrzenia na politykę oczyma tego myśliciela i wskazanie kluczowych pojęć, które pojawiają się w jego ujęciu oraz możliwości wykorzystania jego koncepcji we współczesnych rozwiązaniach nie tylko w sferze polityki. Słowa kluczowe: etyka, moralność, polityka, machiawelizm, Niccolo Machiavelli.

DOI:10.7862/rz.2015.hss.40

Przesłano do redakcji: wrzesień 2015

Przyjęto do druku: październik 2015

\footnotetext{
${ }^{27}$ Z. Stawrowski, O niemoralności i moralności polityki: http://www.opoka.org.pl/biblioteka///IK/polityka_moraln2.html
} 